\title{
Degradation of Synthetic Agro wastewater (Fipronil) using Electro Coagulation Process by Iron Electrodes
}

\author{
Ramya Thangamani ${ }^{1}$, Karthikeyan Velayutham², Thanarasu Amudha ${ }^{2}$, Anuradha Dhanasekaran ${ }^{3}$, \\ Sivanesan Subramanian*
}

${ }^{1}$ Environmental Engineering Laboratory, Department of Environmental Sciences, Bharathiar University, Coimbatore, India.

${ }^{2}$ Department of Applied Science \& Technology, Alagappa College of Technology, Anna University, Chennai, India.

${ }^{3}$ Department of Biotechnology, Anna University, Chennai, India.

*Corresponding author: Sivanesan Subramanian, Department of Applied Science \& Technology, Chennai, India, Phone No. +91 9444960106, email: sivanesh1963@gmail.com.
Received Date: October 29, 2018

Published Date: November 21, 2018

\begin{abstract}
The electrocoagulation of fipronil (insecticide) contaminated wastewater by Iron anodes has been investigated. During the various stages of electrolysis, parameters such as COD, chloride ion concentration, Fluoride were examined and discussed. The maximum chemical oxygen demand (COD) removal efficiency $70 \%$, chloride $62 \%$, fluoride $40 \%$ was achieved at pH 7 , operated at the current density of $7.5 \mathrm{~mA} / \mathrm{cm}^{2}$, electrolyte $(\mathrm{NaCl})$ concentration of $.1 \mathrm{M}$ and at $120 \mathrm{~min}$ of electrolysis using iron anode. A neutral $\mathrm{pH}$ showed the maximum reduction of COD compared with alkaline and acidic $\mathrm{pH}$. Increase in current density and process time led to the increase in COD removal. The experimental results showed that the electrochemical oxidation process could effectively reduce the COD from the fipronil contaminated wastewater. The degradation of fipronil was analyzed and confirmed by GC-MS and intermediate produced during the process.
\end{abstract}

Keywords: Fipronil; Phenylpyrazoles; COD; Fluoride; Chloride; pH7; Iron electrode; Pesticide; Degradation; GC-MS

\section{Introduction}

The wide use of pesticides gives rise to serious ecological problems due to their negative environmental effects. The surface and ground water contamination by pesticides is an important problem that the scientists are dealing with over the years. Fipronil (insecticide) belongs to a new class of insecticides known as phenylpyrazoles. The complete degradation of fipronil contaminated waste water is a very challenging task. Various innovative technologies have been proposed for the removal of pesticides namely photocatalytic oxidation [1], ultrasonic radiation [2], bioremediation [3] and thermal desorption [4]. They are neither cost effective, nor ecofriendly, nor involving low concentrations. In recent years, there has been an increasing interest in the use of electrochemical methods for the treatment of recalcitrant toxic wastes. Electrocoagulation methods have been successfully utilized in the purification of olive oil wastewaters [5], domestic sewage [6], landfill leachate [7], tannery wastes [8] and textile wastes [9 \& 10]. These methods are environmentally friendly, and they do not form new toxic wastes. Hence, this work investigates the degradation of fipronil contaminated synthetic water using iron electrodes in the electro coagulation process.

\section{Experimental Materials and Methods}

\section{Instruments and analytical procedures}

Electrochemical reactor, an acrylic tank measuring $15 \mathrm{~cm} \times 15$ $\mathrm{cm} \times 15 \mathrm{~cm}$ with a capacity of about $3.0 \mathrm{~L}$, fitted with electrodes was used to conduct the experiments. Metallic iron rods with a purity of $98 \%$ and each rod measuring $0.6 \mathrm{~cm}$ in diameter and $12 \mathrm{~cm}$ in length were used as an electrode for electrocoagulation. Seven such rods connected to a common rod, formed the anode assembly, and an equal number of rods with similar arrangement formed the cathode assembly. The gap between the anode and cathode was maintained at $2 \mathrm{~mm}$ to minimize the ohmic losses. The entire electrode assembly was placed on non-conducting wedges fixed to the bottom plate of the electrocoagulation reactor. The total surface area of the electrode was calculated to be $312 \mathrm{~cm}^{2}$.

\section{Parameters}

Chemical oxygen demand test was performed according to the standard method of examination of water and waste water (APHA 1995). The percentage of pesticide mineralization was evaluated from the measurement of COD. Chloride was estimate by titration 
method and fluoride was examined by colorimetric method using spectrophotometer $(570 \mathrm{~nm})$.

\section{Result and Discussion}

\section{Different pH on COD}

The initial $\mathrm{pH}$ of the solution was of vital importance in the performance of the electro coagulation process. Due to oxidation in an electrolyte system, iron produces monomeric form of ions, Fe $(\mathrm{OH}) 3$ and polymeric hydroxyl complex such as: $\mathrm{Fe}\left(\mathrm{H}_{2} \mathrm{O}_{6}{ }^{3+}, \mathrm{Fe}\right.$ $\left(\mathrm{H}_{2} \mathrm{O}\right)_{5}{ }^{2+}$, Fe $\left(\mathrm{H}_{2} \mathrm{O}\right)_{4}(\mathrm{OH})^{2+}$, Fe $\left(\mathrm{H}_{2} \mathrm{O}\right)_{8}(\mathrm{OH})_{2}{ }^{4+}$ and $\mathrm{Fe}_{2}\left(\mathrm{H}_{2} \mathrm{O}\right)_{6}(\mathrm{OH})_{4}{ }^{4+}$ depending upon the $\mathrm{pH}$ of the aqueous medium. The generation of metal ions takes place at the anode and the hydrogen gas gets released at the cathode. The hydrogen gas helps in the flotation of the flocculated particles out of the water. To study the effect of initial $\mathrm{pH}$ on COD, experiments were carried out by varying the initial $\mathrm{pH}$ from 3 to 9 and at $60 \mathrm{~min}$ of electrolysis time. The supporting electrolyte concentration of $0.1 \mathrm{M} \mathrm{NaCl}$ and applied current density of $2.5 \mathrm{~mA} / \mathrm{cm}^{2}$ was maintained for all the experiments. The results reveal that the maximum COD removal of iron (51\%) was achieved at neutral pH (Figure 1). Ghernaout D et al. [11] carried out experiments to measure the chemical dissolution rate of iron electrodes at various $\mathrm{pH}$. It was observed that the dissolution rate of iron was much less at the acidic and the basic $\mathrm{pH}$ increased significantly at neutral $\mathrm{pH}$. The chemical dissolution of iron occurs via oxidation of iron electrode with simultaneous reduction of water to form hydrogen. From this study it has been confirmed that electrocoagulation processes are strongly $\mathrm{pH}$ dependent. These results can be explained by the fact that COD removal was charged by neutral $\mathrm{pH}$.

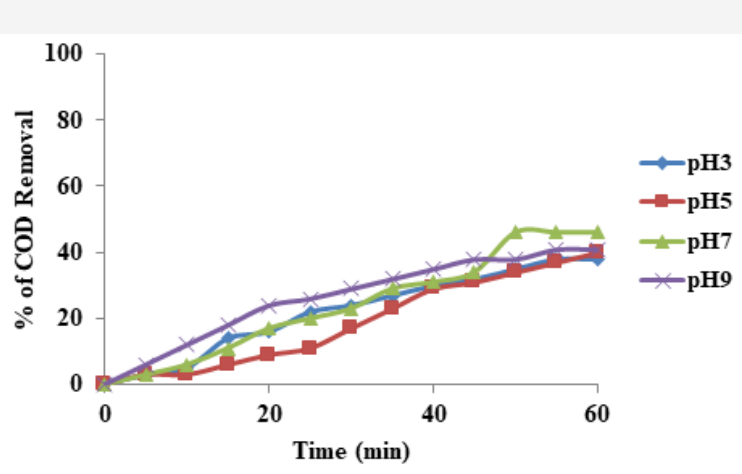

Figure 1: Different $\mathrm{pH}$ on COD.

\section{Different pH on chloride}

In general, $\mathrm{NaCl}$ was used to obtain conductivity in electrocoagulation process. The conductivity of the wastewater was adjusted to the desired levels by adding an appropriate amount of $\mathrm{NaCl}$. The effect of $\mathrm{NaCl}$ concentration on the removal \% of the chloride is shown in Figure 2. Increase in the concentration of $\mathrm{NaCl}$ salt in solution leads to the increase in conductivity of the solution and current density. The higher ionic strength will generally cause an increase in current density at the same cell voltage or, equivalently, the cell voltage decreases with increasing wastewater conductivity at constant current density. Consequently, the necessary voltage for attaining a certain current density will be diminished and the consumed electrical energy will decrease. According to [12] $\mathrm{Cl}_{2}$ and $\mathrm{OCl}^{-}$are the products of anodic discharge with the presence of chlorides in the solution. Hence, addition of $\mathrm{NaCl}$ not only increases the conductivity but also contributes to the strength of oxidizing agents. To study the effect of initial $\mathrm{pH}$ on Chloride removal, experiments were carried out by varying the initial $\mathrm{pH}$ from 3 to 9 and at $60 \mathrm{~min}$ of electrolysis time. The supporting electrolyte $\mathrm{NaCl}$ concentration of $0.1 \mathrm{M}$ and applied current density of $2.5 \mathrm{~mA} / \mathrm{cm}^{2}$ was maintained for all the experiments. The maximum chloride removal was $60 \%$ of iron electrode at neutral $\mathrm{pH}$.

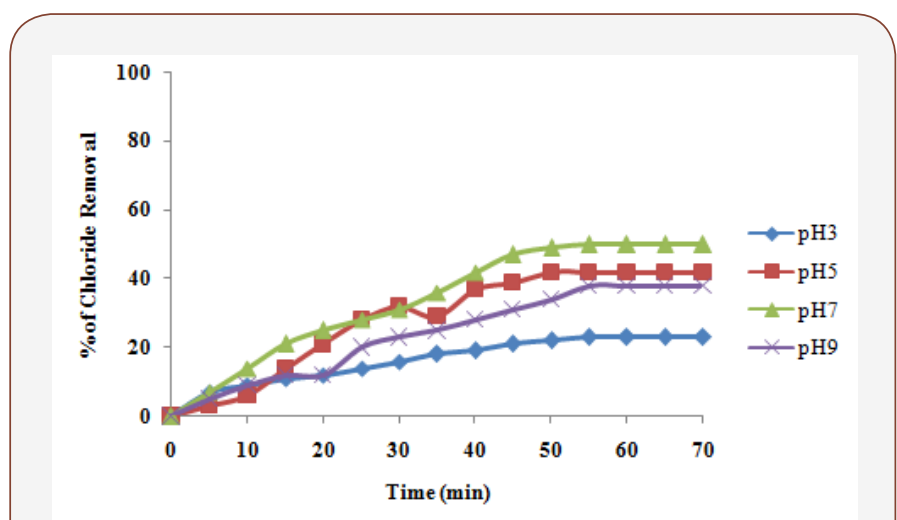

Figure 2: Different $\mathrm{pH}$ on chloride.

\section{Different $\mathrm{pH}$ on fluoride}

It has been established in previous studies [13 \& 14] that initial $\mathrm{pH}$ has a considerable effect on the efficiency of the electrocoagulation process. Also, as observed by other investigators the $\mathrm{pH}$ of the medium changed during the process depending on the type of electrode material and initial pH. Meanwhile, electrocoagulation process exhibited some buffering capacity, especially in alkaline medium, which prevents high changes in $\mathrm{pH}$ [15]. The results of this research showed that fluoride removal efficiency in acidic conditions (pH5) was better than alkaline and neutral conditions. Effect of different $\mathrm{pH}$ was investigated using the initial $\mathrm{pH}$ values of 3, 5, 7 and 9 at the current density $2.5 \mathrm{~mA} / \mathrm{cm}^{2}$. As can be seen from Figure 3 the highest removal of fluoride was obtained at $\mathrm{pH}$. The initial fluoride concentration of $20 \mathrm{ppm}$ was reduced to the $1.4 \mathrm{ppm}$ after 60 minutes of electrocoagulation.

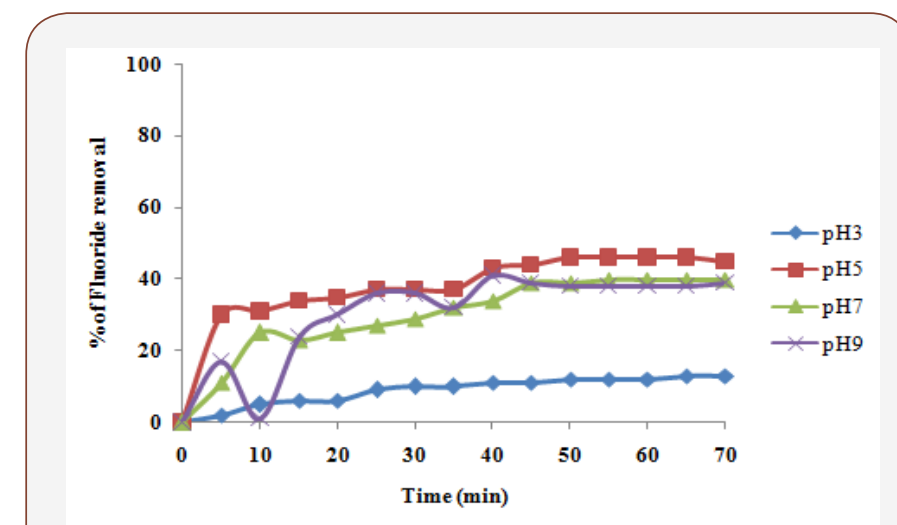

Figure 3: Different $\mathrm{pH}$ on fluoride. 


\section{Different current density on COD}

In whole of the electrocoagulation processes, applied current density was one of the most important parameters for controlling the reaction rate within the reactor. It is well known that the amount of applied current density determines the coagulant production rate and adjusts the rate and size of the bubble production, and hence affects the growth of flocks [16]. Hence this study was carried out by varying applied current density at $2.5,5.0$, and $7.5 \mathrm{~mA} / \mathrm{cm}^{2}$ with the supporting electrolyte concentration of $2.5 \mathrm{~g}$ and at neutral $\mathrm{pH}$ 7. A maximum of $70 \%$ of COD was removed by electrocoagulation using iron electrode (Figure 4).

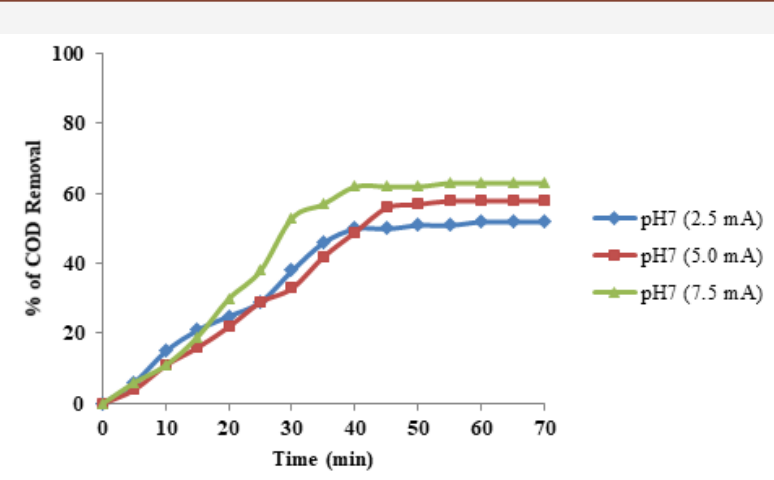

Figure 4: Different power density on COD.

\section{Different current density on chloride}

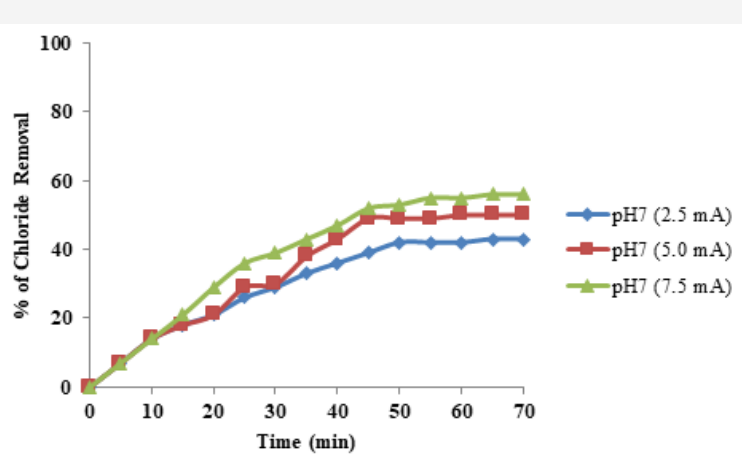

Figure 5: Different power density on chloride.

In general, $\mathrm{NaCl}$ was used to obtain conductivity in electrocoagulation process. The conductivity of the wastewater was adjusted to the desired levels by adding an appropriate amount of $\mathrm{NaCl}$. The effect of $\mathrm{NaCl}$ concentration on the removal $\%$ of the pesticides is shown in Figure 5. When the concentration of $\mathrm{NaCl}$ salt in solution increases, conductivity of the solution and the current density also increase. The higher ionic strength will generally cause an increase in current density at the same cell voltage or, equivalently, the cell voltage decreases with increasing wastewater conductivity at constant current density. Consequently, the necessary voltage for attaining a certain current density will be diminished and the consumed electrical energy will decrease. According to [12] $\mathrm{Cl}_{2}$ and $\mathrm{OCl}^{-}$are the products of anodic discharge with the presence of chlorides in the solution. Hence, addition of $\mathrm{NaCl}$ not only increases the conductivity but also contributes to the strength of oxidizing agents. To study the effect of initial $\mathrm{pH}$ on chloride removal, experiments were carried out by varying the $\mathrm{pH}$ from 3 to 9 and at $60 \mathrm{~min}$ of electrolysis time. The supporting electrolyte $\mathrm{NaCl}$ concentration of $0.1 \mathrm{M}$ and applied current density of $2.5 \mathrm{~mA} / \mathrm{cm}^{2}$ was maintained for all the experiments. The maximum chloride removal was $62 \%$ of iron electrode at neutral $\mathrm{pH}$.

\section{Different current density on fluoride}

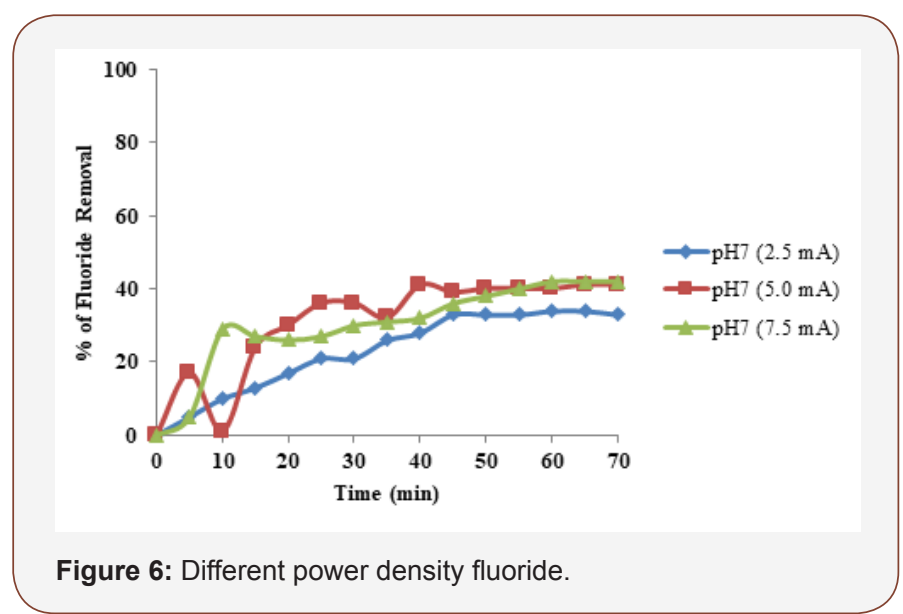

Preliminary laboratory testing of the electrolysis cell involved determining the effect of applied voltage on the efficiency of fluoride removal. It is well known that electrical current not only determines the coagulant dosage rate but also the bubble production rate, size and the floc growth, [17] which can influence the treatment efficiency of the electrocoagulation. Therefore, the effect of current density or applied voltage (electrical potential) on the fluoride removal was investigated. The removal efficiency increased significantly with the increase in current density. The highest electrical potential $\left(7.5 \mathrm{~mA} / \mathrm{cm}^{2}\right)$ produced the quickest treatment with $40 \%$ reduction occurring after only $60 \mathrm{~min}$ (for all concentrations) and the lowest fluoride removal efficiency occurred in the lowest electrical potential $\left(2.5 \mathrm{~mA} / \mathrm{cm}^{2}\right)$ and initial concentrations of $1000 \mathrm{ppm}$. This was ascribed to the fact that at higher voltage the amount of iron oxidized increased, resulting in a greater amount of precipitate for the removal of pollutants. In addition, it was demonstrated that bubbles density increases and their size decreases with increasing current density [18 \& 19] resulting in a greater upwards flux and a faster removal of pollutants and sludge flotation. As the current decreased, the time needed to achieve similar efficiencies increased and the results of this research confirm this fact. This expected behavior has been explained by the fact that the treatment efficiency is mainly affected by charge loading $(\mathrm{Q}=\mathrm{It}$ ), as reported by [20]. However, the cost of the process was determined by the consumption of the sacrificial electrode and the electrical energy which economically are the advantages of this method. These results suggest $7.5 \mathrm{~mA} / \mathrm{cm}^{2}$ as an optimal electrical potential for the treatment of effluents containing fluoride, since it ensures the quickest removal rate with the lowest cost. The current density was effective parameter that controls the reaction rate in the electrochemical systems, and it determines the amount of $\mathrm{Fe}^{2+}$ ions released by the anode. To determine the effect 
of current density, experiments were performed at initial $\mathrm{pH}$ of 7 and current density was $2.5,5.0$, and $7.5 \mathrm{~mA} / \mathrm{cm}^{2}$. The maximum fluoride removal of iron electrode was (F- $40 \%$ ) with the applied current density of $7.5 \mathrm{~mA} / \mathrm{cm}^{2}$. After $60 \mathrm{~min}$ electrocoagulation, the removal efficiencies are almost constant. Therefore, the electrocoagulation process should be stopped to reduce energy consumption (Figure 6).

\section{Different process time on COD}

Similar to current density effects on electrode dissolution, reasonable electrolysis duration should be provided to ensure adequate application of current to the sacrificial electrodes where the metal ions released by the dissolution forms metal hydroxide species in the electrocoagulation reactor. The effects of operating time on the electrocoagulation to the COD removal efficiency depend directly on the concentration of ions produced by the electrodes which in turn depends upon time. As the value of time increases, the concentration of iron ions and their hydroxide flocs also increases. The study was carried out by varying electrolysis time up to $120 \mathrm{~min}$ at the supporting electrolyte concentration of $2.5 \mathrm{mg}$ by applied current density of $7.5 \mathrm{~mA} / \mathrm{cm}^{2}$ and at neutral $\mathrm{pH}$ 7. Iron electrode in Figure 7 indicates that the removal efficiency drastically increases in the first $60 \mathrm{~min}$, reaching over $70 \%$. In the latter, the degradation efficiency increases slightly but reaches only $56 \%$ at $120 \mathrm{~min}$.

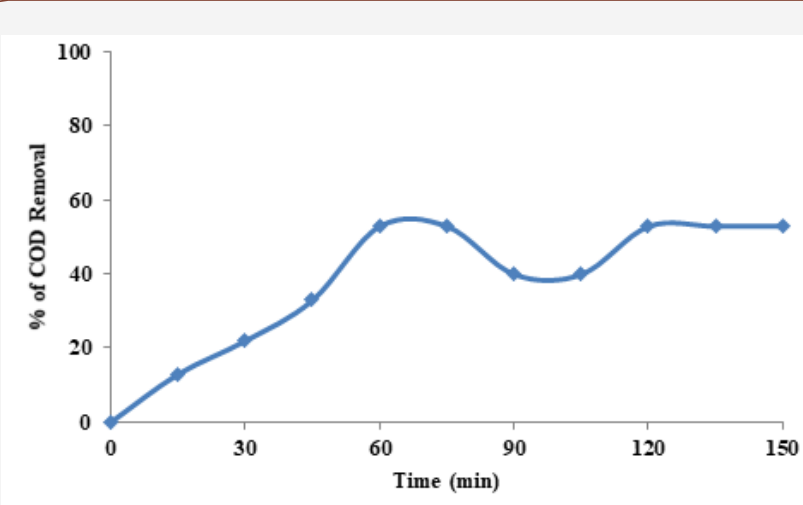

Figure 7: Different run time on COD.

\section{Different process time on chloride}

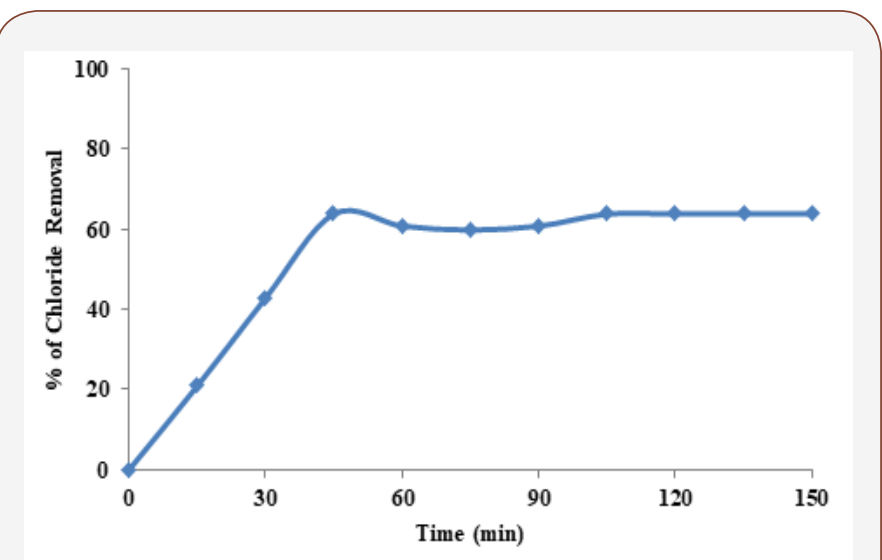

Figure 8: Different run time on chloride.
The chloride removal efficiency depends directly on the concentration of ions produced by the electrodes which in turn depends upon time. As the value of time increases, the concentration of iron ions and their hydroxide flocs also increases. The study was carried out by varying electrolysis time up to 120 $\mathrm{min}$ at the supporting electrolyte concentration of $2.5 \mathrm{~g}$ by applied current density of $7.5 \mathrm{~mA} / \mathrm{cm}^{2}$ and at neutral $\mathrm{pH} 7$. Iron electrode in Figure 8. indicates that the removal efficiency drastically increases in the first $60 \mathrm{~min}$, reaching over $62 \%$. In the latter, the degradation efficiency increases slightly but attains only $65 \%$ at $120 \mathrm{~min}$.

\section{Different process time on fluoride}

Electrolysis time also affects the treatment efficiency of the process. Electrolysis time determines the production rate of $\mathrm{Fe}^{2+}$ or $\mathrm{Fe}^{3+}$ ions. Figure 9 shows the effect of electrolysis time on the removal $\%$ of the pesticides waste water under the following operating conditions: $1000 \mathrm{ppm}$ initial dose of pesticides, $\mathrm{pH}$ of 7, current density of $7.5 \mathrm{~mA} / \mathrm{cm}^{2}$, temperature of $25{ }^{\circ} \mathrm{C}$. According to the plot of Figure 9 the removal \% increases with the increase of electrolysis time up to 150 minutes. It could be seen from Figure 9 iron electrode that the removal efficiency drastically increases in the first $60 \mathrm{~min}$, reaching over $45 \%$ and gradually maintains the fluoride removal efficiency within $150 \mathrm{~min}$.

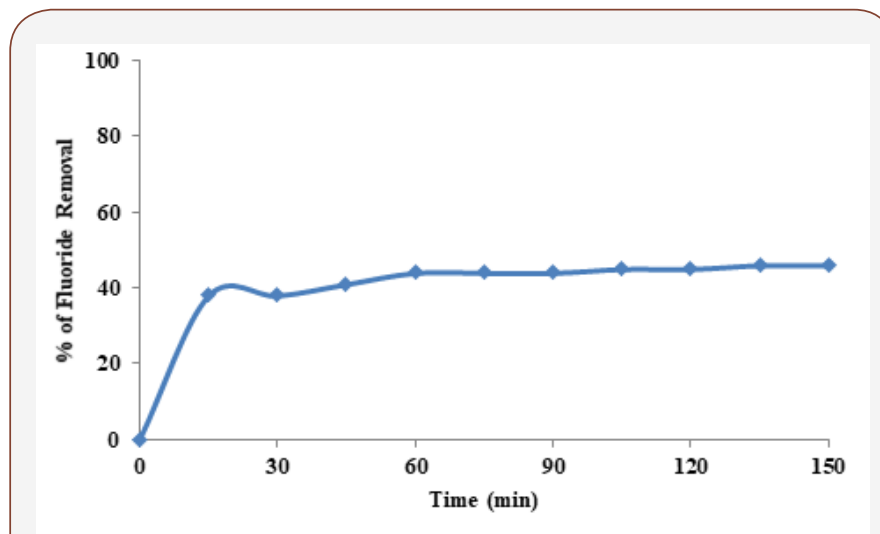

Figure 9: Different run time on fluoride.

\section{GC-MS Analysis}

The intermediate compound formed during the degradation of fipronil using iron anode was identified by GC-MS spectroscopy. It was necessary to discuss the role of coagulation played in the removal of COD, chloride, fluoride which are mainly attributed to the radicals due to the electrooxidation generation of oxidant species (hydroxyl radical, hydrogen peroxide, hypochloric and hypochlorite ions depending on the $\mathrm{pH}$ ).

As shown in Table $1 \&$ Table 2, the byproducts were detected at $5 \mathrm{~min}$ and at $\mathrm{pH} 7$ for electrooxidation process. Figure 10 shows that after 5 min electrocoagulation process the major fragments are generated in degradation process. The degradation of the pesticide and electrocoagulation causes significant mineralization which results in the formation of substituted (Tungsten disulfide, 2,3-dibromopropionamide 230.9, Tantalum 178.0, Sodium Sulfate 142.8, Sulfonyl amide $\left(\mathrm{C}_{24} \mathrm{H}_{25} \mathrm{NO}_{2} \mathrm{~S}\right)$ 98.1). 

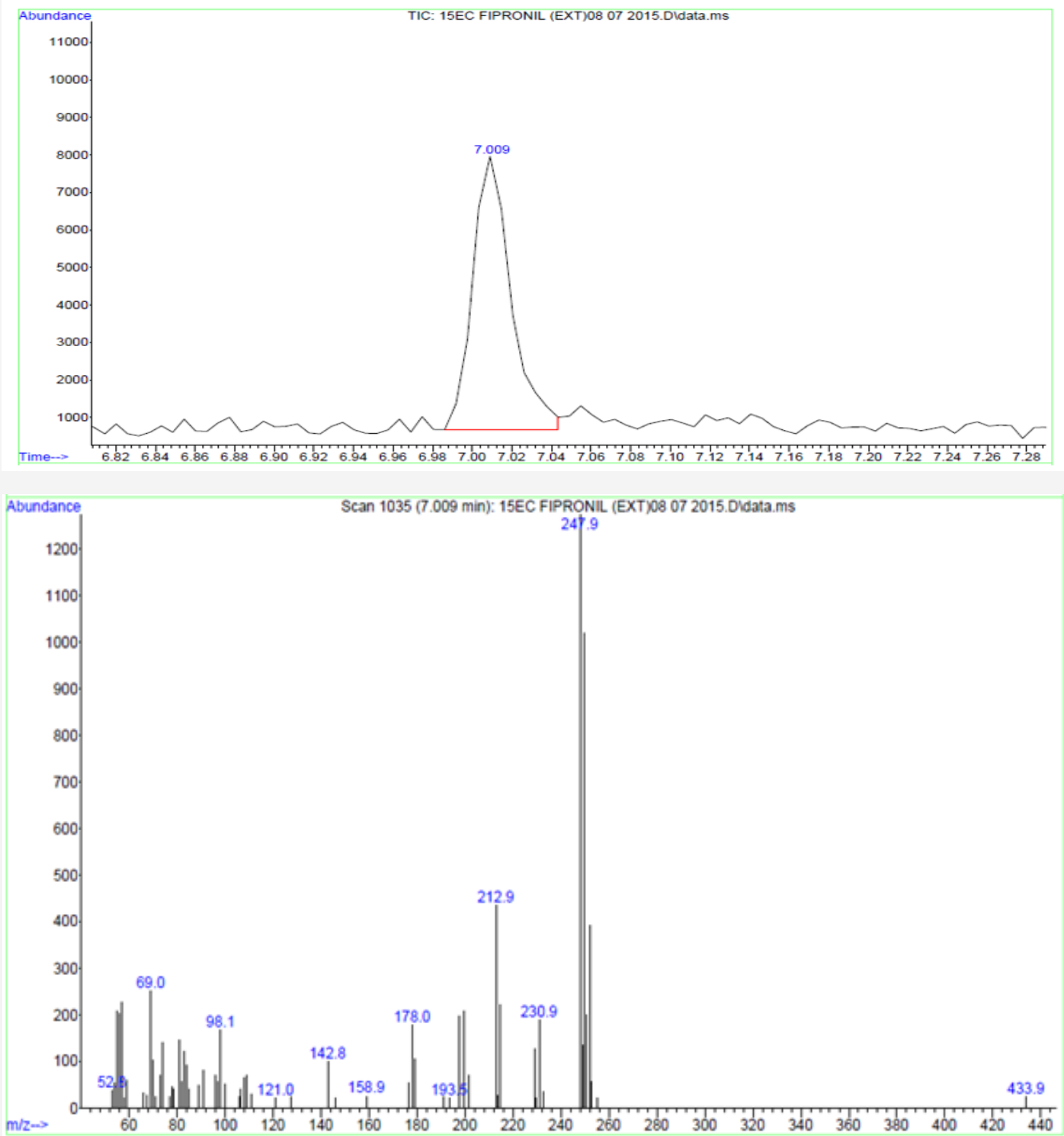

Figure 10: GC-MS analysis.

Table 1: Physical and Chemical Properties of Fipronil.

\begin{tabular}{|c|c|}
\hline Sample Details & Characteristics \\
\hline Name & Fipronil \\
\hline IUPAC Name & $\begin{array}{c}\text { (RS)-5-Amino-1- [2,6-dichloro-4 (trifluorometh- } \\
\text { yl)phenyl]-4-(trifluromethysulfinyl) phyra- } \\
\text { zole-3-carbonitrile }\end{array}$ \\
\hline Colour & White \\
\hline Chemical Formula & C. $_{12} \mathrm{H}_{4} \mathrm{Cl}_{2} \mathrm{~F}_{6} \mathrm{~N}_{4} \mathrm{OS}$ \\
\hline Melting Point & $200.5^{0} \mathrm{C}$ \\
\hline Molecular Weight & \\
\hline
\end{tabular}

Table 2: List of intermediate compound present in fipronil degradation using electrocoagulation process by iron electrodes.

\begin{tabular}{|c|c|}
\hline COMPOUNDS & MOLECULAR WEIGHT \\
\hline Tungsten disulfide (WS2) & 247.9 \\
\hline 2,3dibromopropionamide (C3H5Br2NO) & 230.9 \\
\hline 2,4Difluorobenzenesulfonyl (F2C6H3SO2Cl) & 212.9 \\
\hline Tantalum (Ta) & 178 \\
\hline Sodium Sulfate (Na 2 SO 4) & 142.8 \\
\hline Sulfonyl amide (RSO2NH2) & 98.1 \\
\hline
\end{tabular}

\section{Conclusion}

Electrocoagulation of a synthetic agricultural waste water containing fipronil was investigated. In this process maximum removal of COD, $\mathrm{Cl}, \mathrm{F}$ was $74 \%, 62.0,40 \%$ was achieved at optimum $\mathrm{pH}$ 7. The degradation efficiency was increased by increasing the power density and run time. The GC-MS and result confirm the maximum degradation of fipronil. Finally, the research finding indicates that electrocoagulation of fipronil using Fe electrode 
was effective, economical process in the degradation of fipronil pesticide.

\section{Acknowledgement}

None.

\section{Conflict of Interest}

No conflict of interest.

\section{References}

1. Matija Cvetnic, Sime Ukic, Hrvoje Kusic, Tomislav Bolanca, Ana Loncaric Bozic (2017) Photooxidative Degradation of Pesticides in Water; Response Surface Modeling Approach. J of Advanced Oxidation Technologies 20(1): 1-14.

2. Pena A, Ruano F, Mingorance MD (2006), Ultrasound-assisted extraction of pesticides from olive branches: a multifactorial approach to method development. J of Anal Bioanal Chem 385(5): 918-925.

3. Radhika M, Kannahi M (2014) Bioremediation of pesticide (Cypermethrin) using bacterial species in contaminated soil. Int J Curr Microbiol App Sci 3(7): 427-435.

4. Nicholas J Martin, Philip A Smith, Carlis W Brown, Nicole L Achee, Gerald T DeLong (2012) Dichlorodiphenyltrichloroethane determination in air by thermal desorption gas chromatography-mass spectrometry. J of Pest Manag Sci 68(10): 1360-7.

5. Nelly Flores, Enric Brillas, Thiam A, Centellas F, Garrido JA, et al. (2018) Electrochemical destruction of trans-cinnamic acid by advanced oxidation processes: kinetics, mineralization, and degradation route. J of Hazardous Materials 24(7): 58-66.

6. Sarala C (2012) Domestic wastewater treatment by electrocoagulation with Fe-Fe electrodes. International Journal of Engineering Trends and Technology 3(4): 1-4

7. Dheeravath Bhagawan, Saritha Poodari, Narala Chaitanya, Surya Ravi, Vurimindi Himabindu, et al. (2017) Industrial solid waste landfill leachate treatment using Electrocoagulation and Biological methods. J of Desalination and water treatment 68: 137-142.

8. Benahmed Daij K, Bellebia S, Bengharez Z (2017) Comparative experimental study on the COD removal in aqueous solutions of pesticides by the electrocoagulation process using monopolar iron electrodes. J of Chemistry International 3(4): 319-327.
9. Behloul M, Grib H, Drouiche N, Abdi N, Lounici $H$, Mameri N (2013) Removal of Malathion Pesticide from Polluted Solutions by Electrocoagulation: Modeling of Experimental Results using Response Surface Methodology. J of Sepration science and technology 48(4): 664672.

10. Ghalwa A, Nasser M, Farhat NB (2015) Removal of Abamectin Pesticide by Electrocoagulation Process Using Stainless Steel and Iron Electrodes. J of Environ Anal Chem 2(3): 1-7.

11. Ghernaout D, Badis A, Kellil A, Ghernaout B (2008) Removal of humic acids by continuous electromagnetic treatment followed by electrocoagulation in batch using aluminium electrodes. J of Desalination 219(1-3): 118-25.

12. Vlyssides G, Papaioannou D, Loizidoy M, Karlis PK, Zorpas AA (2000) Testing an electrochemical method for treatment of textile dye wastewater. Waste Manage J of Waste Manag 20(7): 569-574.

13. Chen G, Chen X, Yue PL (2000) Electrocoagulation and Electro flotation of Restaurant Wastewater. J of Environ Eng 126(9): 858-863.

14. Adhoum N, Monser L, Bellakhal N, Belgaied JE (2004) Treatment of Electroplating Wastewater Containing $\mathrm{Cu}^{2+}, \mathrm{Zn}^{2+}$ and $\mathrm{Cr}$ (VI) by Electrocoagulation. J of Chem Eng Process 112(3): 207-13.

15. Bayramoglu M, Eyvaz M, Kobya M (2007) Treatment of the Textile Wastewater by Electrocoagulation: Economical Evaluation. J of Chem Eng 128(2,3): 155-161.

16. Chompey Den, Lawrence P Belo, Elaine G Mission, Hirofumi Hinode, Leonila C Abella et al. (2016) Experimental investigations of the effects of current density during the electrocoagulation of bio-treated distillery wastewater using Aluminum-Aluminum Electrode Pair. J of Research Congress 4: 7-9.

17. Holt PK, Barton GW, Mitchell CA (2005) The future for electrocoagulation as a localised water treatment technology. J of Chemosphere 59(3): 355367.

18. Bazrafshan E, Mesdaghinia AR, Naseri S, Vaezi F (2007) Chromium $\left(\mathrm{Cr}^{+6}\right)$ removal and Wastewater J of water and wastewater 62: 28-34.

19. Khosla NK, Venkachalam S, Sonrasundaram P (1991) Pulsed electro generation of bubbles for electro flotation. J of Applied Electrochemistry 21(11): 986-990.

20. Chen G, Chen X, Yue PL (2000) Electrocoagulation and Electro flotation of Restaurant Wastewater. J of Environ Eng 126(9): 858-863. 